\title{
The Role of Independent Commissioners and Audit Committee in Moderating the Influence of Related Party Transactions on Firm Value
}

\author{
Deni Darmawati ${ }^{1}$, Triyanto ${ }^{2}$ \\ \{deni_darmawati@trisakti.ac.id ${ }^{1}$, triyanto.suwito@gmail.com² \\ Faculty of Economic and Business Universitas Trisakti, Jakarta, Indonesia ${ }^{1,2}$
}

\begin{abstract}
This research aims to investigate the impact of related party transactions on firm value moderated by the Independent Commissioner and the Audit Committee. The sample used in this research is companies in the manufacturing sector that were listed on Indonesia Stock Exchange in period 2017-2019. Purposive sampling method was used to produce a sample of 167 firm-years. By using multiple regression analysis, this study found related party transactions in assets and liabilities have a positive effect on firm value, while related party transactions on sales and expenses have no effect on firm value. This study also finds that the Independent Commissioner weakens the positive effect of related party transactions on assets and liabilities on firm value, while the Audit Committee strengthens the positive effect of related party transactions on assets and liabilities on firm value. The results of this study suggest that the efficient transaction hypothesis is supported. Affiliated companies in one business group can use resources together, so that they can benefit from economies of scale and economies of scope, transactions like this are included in the efficient category because they benefit shareholders as a whole. This study also shows the role of the Audit Committee in encouraging companies to conduct efficient related party transactions.
\end{abstract}

Keywords: Related Party Transactions; Independent Commissioners; Audit Committee; Firm Value

\section{Introduction}

Ownership structure that concentrated on controlling shareholders increases the potential agency problems between controlling shareholders and minority shareholders. This is because the controlling shareholder has an advantage in obtaining information of the condition of the company compared to minority shareholders. As a result of concentrated ownership structure, minority shareholders might be subjected to harmful practices through related party transactions [1]. As further stated by [1], there are two categories of related party transactions: firstly, abusive transactions which are in accordance with the conflict-of-interest hypothesis, and secondly, profitable/efficient transactions which are in accordance with the efficient transaction hypothesis. Affiliated companies in one business group can use abusive related 
party transactions in favour of the controlling shareholders by diverting internal resources out of the company. Meanwhile, affiliated companies in one business group can use resources together, so they can benefit from economies of scale and economies of scope, transactions like this are included in the efficient category because they benefit shareholders as a whole.

Statement of Financial Accounting Standards (PSAK) 7 regulates the disclosure of related party transactions in financial statements. Disclosure of financial information in the annual report has a role in conveying information on the condition of the company. Insufficient information in financial statements often leads to business scandals that harm stakeholders. Therefore, accounting information is one of the important information used by investors in making investment decisions. The information that is reacted by the market shows that information has a relevance value [2].

Related party transactions are the information that is reacted by the market. Disclosure of key management information, which is one of the types of related party transactions, can influence decision making by investors because the company's performance can be represented by the extent of disclosure of the company's key management compensation [3], [4]. The amount of compensation for key management indicates the potential for opportunistic earnings management, because management can use its authority to present information that can increase the rewards they get. [5] state that key management compensation will be able to influence the entity's operational and risk decisions. [2] also found that the stock market reacts negatively following the announcement of related party transaction of sales and purchases. This is because there a potential for management discretion over the related party transactions to report management performance that not in accordance with the actual economic condition of the entity. [6] state that a firm value is lower when they have transactions with related parties. This because the firm is more likely to encourage utilizing related party transactions as a way of expropriating minority shareholders.

However, [7] find that related party transactions have a positive impact on company value when the length of service of the Independent Commissioner is long enough because they are considered to have a positive reputation that can help supervise and reduce expropriation of minority shareholders. [8] has found that related party transaction of expense are carried out for the purpose of cost efficiency, so that it can help increase firm value. The same thing was conveyed by [9] who stated that the related party transaction of sales and expense were for efficiency through reducing transaction costs. Besides, [10] reveal that although related party transaction of asset and liability are used as a means to carry out the personal interests of controlling shareholders, the use of related party transactions of asset and liability can also reduce the risks associated with conducting transactions with third parties, such as the timing of transactions with third parties. and transaction fees. [11] prove that related party transactions of asset could help improve the company value because it is considered a form of support to improve company performance.

The inconsistency of the research results indicates that there are contingency factors regarding the influence of related party transactions with firm value. In order to reduce abusive related party transactions, a well implemented Good Corporate Governance (GCG) plays a key role. The better the quality of corporate governance, the smaller the number of abusive related party transactions. The role of Independent Commissioners in corporate governance is very important, because they represent unaffiliated parties in supervising and providing advice related to the management of the company. [12] stated that Independent Commissioners are likely to help improve the role of commissioners to ensure that there is no pressure on various parties. 
[13] states that corporate governance is able to overcome problems between controlling and minority shareholders. Being a part of a good corporate governance, the audit committee has a role in improving the quality of supervision, so that information asymmetry will be reduced. An effective audit committee will improve the quality of disclosure of financial statements, including disclosure of related party transactions [14], [15]. [16] states that the audit committee can play a role in reducing management's opportunistic behavior through a supervisory mechanism for the financial reporting process. [17] found that the accounting expertise of audit committee members positively affect the disclosure of related party transactions. Based on the explanations above, further study is still needed by including contingency factors. [18] state that $90 \%$ of companies in Indonesia practice related party transactions, so that the motivation of companies in conducting related party transactions, whether based on abusive or efficient reasons, is very interesting to study.

The purpose of this research is to investigate the impact of related party transactions on firm value, with Independent Commissioners and audit committees as contingent factors. The number of companies that practice related party transactions shows that these practices are common and are disclosed in the financial statements. The role of Independent Commissioners and audit committees in supervising the practices of these related parties is important for investors in assessing the company. The results of this study indicate the efficient transaction hypothesis is supported. Affiliated companies in one business group can use resources together, so that they can benefit from economies of scale and economies of scope, transactions like this are included in the efficient category because they benefit shareholders as a whole. This study also shows the role of the Audit Committee in encouraging companies to conduct efficient related party transactions.

\section{Literature Review and Hypothesis Development}

\subsection{Theories and Concepts}

\subsubsection{Agency Theory}

Agency theory explains the correlation between principals (shareholders) and agents (management). As stated by [19], agency relationship is an arrangement between the principal (owner or shareholder) who appointing another person that is the agent (manager) to run the company's operations for the benefit of the principal. There are conflicts that can arise from the agency relationship due to differences in interests between the principal and the agent. [20] state that there are two types of agency conflict, that are Type I and Type II. Type I agency conflict is a problem that arises between the proprietor of the company as the principal and the management as the agent. Type II agency conflict is a problem that arises between the majority shareholder and the minority shareholder.

In related party transactions, agency problems occur between management who is the representative of the controlling shareholder and the minority shareholder. Related party transactions might be used by controlling shareholders to expropriate and harm minority shareholders [21]. [22] stated that management as the party who run the company certainly has more information than shareholders. The majority shareholders with a prioritized and greater rights of control in the company can also get more information from the management. This causes a condition of information asymmetry between majority and minority shareholders or is called asymmetric information. 


\subsubsection{Signalling Theory}

The signalling theory is based on the assumption that there is an information asymmetry problem. Signalling theory explains that managers provide signals for the purpose of reducing information asymmetry. Leland \& Pyle (1977) in [23] state that according to signalling theory, there is an incentive for company managers to convey good information about the company to potential investors through signals in reporting on the company's annual report with the aim of increasing firm value. Information on related party transactions can be useful information for investors in making decisions.

\subsubsection{Related Party Transactions}

According to PSAK No. 7 of 2018, related party transactions could be defined as the transfer of resources, services or obligations between the reporting entity and related parties, whether or not at a cost. Related parties include transactions with companies with proprietary relationships, individuals as owners, or employees with significant influence, closest family members of these individuals, and companies that are substantially owned by these individuals. Related party transaction can be categorized as profitable (efficient) and detrimental (abusive). [24] stated that related party transactions can increase company efficiency, because it can save the times and costs when conducting related party transactions, so that company performance can increase. However, related party transactions can also cause losses, especially for minority shareholders, because the majority shareholders can control the company, so that the company's assets can be transferred out for the benefit of the majority shareholders.

\subsubsection{The Firm Value}

[25] states the several value concepts to describe firm value, including: nominal value, market value, intrinsic value, book value, and liquidation value. The firm value is a positive signal for investors, that a high firm value reflects the prosperity of high shareholders. In some research, the value of the company is commonly approached with several measuring tools such as: price to book value (PBV), dan rasio tobin's Q [26]. Firm value can be measured with Tobin's Q ratio [6], [24]. The Tobin's $Q$ value is obtained from the sum of market capitalization value and book value of debt, then divided by the assets book value [21].

\subsubsection{Independent Commissioner}

One of the corporate governance mechanisms is the existence of independent commissioners. [12] stated that Independent Commissioners are commissioners from outside parties, not affiliated with any party, particularly major shareholders, individuals of the board of executives and other individuals of the board of commissioners who are appointed based on the decision of the General Meeting of Shareholders (GMS). One of the main benefits of having an independent commissioner is to protect the interests of minority shareholders and other stakeholders and to maintain the principle of fairness. 


\subsubsection{Audit Committee}

The audit committee is one of the supporting organs for the board of commissioners. [12] state that the audit committee works independently and professionally who is responsible for maintaining public trust in the accounting system, auditing, and other control systems, so that the elements of control remain optimal.

\subsection{Conceptual Framework}

Indonesian companies are mainly characterized by their concentrated shareholding structure and the possibility of transactions with related parties, which are often invaded by minority shareholders. Therefore, related party transactions will have a negative effect on firm value. The duty of independent commissioners and audit committee could take part in preventing the abuse of related transactions, which is expected to weaken the negative impact of related transactions on the company's value. Based on the description above, the conceptual framework in this study is depicted in Figure 2 as follows:

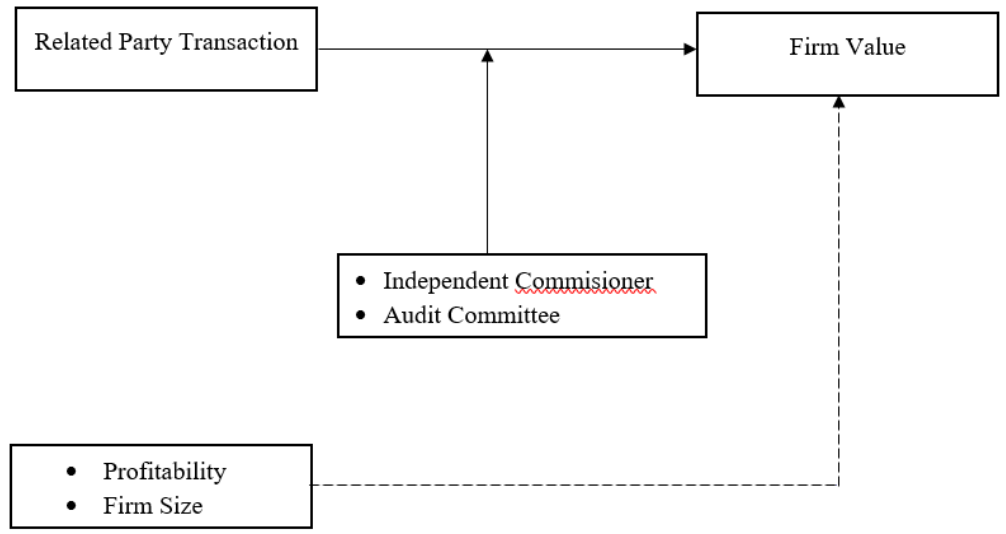

Fig. 1. Conceptual Framework

\subsection{Hypothesis Development}

The characteristics of many companies in Indonesia are concentrated ownership and the ownership structure is family ownership [27]. This encourages company decisions to prioritize transactions with related parties rather than transactions with third parties, so that it will cause a negative market reaction and reduce firm value [6], [21]. [28] state that companies have high controlling shareholder ownership will conduct transactions with related parties with the aim of transferring wealth from minority shareholders to majority shareholders, causing agency conflicts between controlling shareholders. and minority shareholders.

H1: The total amount of related party transactions has a negative effect on firm value.

[18] state if the corporate governance mechanism is inadequate, there will be an assumption that related party transactions contain elements of expropriation so that it will 
ultimately reduce the value of the company. The same thing was found by [29] who stated that in financial statements, related party transactions must be disclosed and the level of disclosure compliance is influenced by good corporate governance mechanisms. With the corporate governance implementation in the company can increase the firm value in the eyes of investors.

The existence of Independent Commissioners is one of the corporate governance mechanisms. Agency theory suggests that managers' decisions should be monitored by independent parties, namely Independent Commissioners to ensure that they act in the interests of shareholders. Independent Commissioners are likely to help in improving the role of the board of commissioners in ensuring that there is no pressure on various parties, so that the work carried out does not involve interference from various parties [12]. In addition to independent commissioners, the audit committee is also a part of the corporate governance mechanism whose function is to ensure that an entity must comply with applicable laws and regulations and ensure that the company has run its business ethically and morally [12].

Based on the description above, we can conclude that Independent Commissioners and audit committees will be able to provide confidence to investors, so the research hypothesis can be presented as follows:

$\mathrm{H} 2$ : Independent Commissioners will weaken the negative effect of related party transactions on firm value.

H3: The audit committee will weaken the negative effect of related party transactions on firm value.

\section{Research Methodology}

\subsection{Variables and Measurements}

The independent variable in this study is Related Party Transactions which is measured by using the size of the transaction. The value for related party transactions is represented by the amount of Related Party Transaction Asset Liability (RPTAL) and Related Party Transaction on Sales and Expenses (RPTSE) [1]. RPTAL is the amount of Related Party Transaction on assets and liabilities which is then divided by the value of equity. While RPTSE is the sum of Related Party Transaction on income and expenses which is then divided by the value of equity. The dependent variable in this study is firm value which is calculated by using the Tobin's Q ratio, which is obtained from the sum of total market capitalization value and book value of debt which is then divided by the assets book value. [6].

The moderating variables in this study are the Independent Commissioner and the Audit Committee. The measurement of the Independent Commissioner variable uses the percentage of Independent Commissioners on the board of commissioners [30], [31]. The measurement of audit committee variables uses the proportion of audit committee members who have expertise in accounting [17]. This study also uses Firm size as the control variable, because several previous studies have proven the effect of Firm size on Firm Value (see for example [6], [32]). Firm size is calculated by the natural logarithm of total assets. Another control variable in this study is Profitability as done by [33] which is calculated by using the return on assets ratio, that is the ratio of the amount of net income divided by total assets. 


\subsection{Research Samples and Data}

This research samples were selected using purposive sampling method by adhering to three separate criterions below:

a. Manufacturing firms listed on the Indonesia Stock Exchange in 2015-2019.

b. Have the data needed in research.

c. Have a positive profit.

The data is taken from the company's annual report published on the company's website. The sample used in this research is companies in the manufacturing sector that were listed on Indonesia Stock Exchange in period 2017-2019. Purposive sampling method was used to produce a sample of 167 firm-years.

\subsection{Data analysis method}

Multiple Regression Analysis is used as a method of analysis for hypothesis testing by using the following equation 1 below:

Firm value $=a+b 1$ Related Party Transactions $+b 2$ Independent Commissioner*Related Party Transactions + b3 Audit Committee*Related Party Transactions + b4 Firm size + b5 Profitability + e

\section{Analysis and Discussion}

\subsection{Descriptive Statistics}

Table 4.1 shows the result of the descriptive statistics done during the data analysis part of this study:

\begin{tabular}{lccccc}
\multicolumn{1}{c}{ Table 1. Descriptive statistics } \\
\hline Variable & $\mathbf{N}$ & $\begin{array}{c}\text { Minimum } \\
\text { Value }\end{array}$ & $\begin{array}{c}\text { Maximum } \\
\text { Value }\end{array}$ & $\begin{array}{c}\text { Average } \\
\text { value }\end{array}$ & $\begin{array}{c}\text { Standard } \\
\text { Deviation }\end{array}$ \\
\hline Firm Value & 167 & 0.068 & 5.732 & 1.459 & 1.009 \\
RPTAL & 167 & 0.000 & 1.078 & 0.139 & 0.194 \\
RPTSE & 167 & 0.002 & 3.380 & 0.573 & 0.737 \\
Independent Commissioner & 167 & 0.290 & 0.670 & 0.412 & 0.088 \\
Audit Committee & 167 & 0.000 & 1.000 & 0.700 & 0.255 \\
Profitability & 167 & 0.000 & 0.390 & 0.062 & 0.054 \\
Firm size & 167 & 25.795 & 33.490 & 28.785 & 1.517 \\
\hline \multicolumn{7}{c}{ Source: Data processed 2021} & &
\end{tabular}

Information:

RPTAL $=$ Related Party Transactions in Asset and Liability

RPTSE $=$ Related Party Transactions in Sales and Expense

As per the result presented in Table 4.1, the conclusions are narrated below:

a. The firm value has a minimum value of 0,068 , that is at PT Kabelindo Murni in 2017 and a maximum value of 5,732, namely at PT Aneka Gas Industri in 2019. The mean value is 1,459 with standard deviation value of 1,009 .

b. The related party transaction as measured using RPTAL has a minimum value of 0,000 , namely at PT Argha Karya Prima in 2017 and a maximum value of 1,078, that is at PT Waskita Beton 2017. The mean value is 0,139 with standard deviation value of 0,194 . 
c. The related party transaction as measured by the RPTSE has a minimum value of 0,002 , namely at PT Emdeki Utama in 2018 and a maximum value of 3,380, that is at PT Wilmar Cahaya Indonesia in 2018. The mean value is 0,057 with standard deviation value of 0,737 .

d. The proportion of Independent Commissioners has a minimum value of 0,290, that is at PT Semen Indonesia in 2017-2019 and a maximum value of 0,670, namely at PT Jembo Cable Company in 2017 and PT Kabelindo Murni in 2018 and 2019. As well as the mean value of 0,412 with standard deviation value of 0,088 .

e. The Audit Committee has a minimum value of 0,000, namely at PT Kino Indonesia and a maximum value of 1 (one), that is at PT Unilever Indonesia in 2017-2018. The mean value is 0,700 with standard deviation value of 0.25

f. The profitability variable has a minimum value of 0.000 , that is at PT Kirana Megatara in 2018 and a maximum value of 0,390 , namely at PT Unilever Indonesia in 2017. The mean value is 0.062 with standard deviation value of 0,054 .

g. The firm size has a minimum value of 25,800, that is at PT Pyridam Farma in 2017 and a maximum value of 33,490 , namely at PT Astra International in 2019. The mean value is 28,785 with standard deviation value of 1,517 .

\subsection{Hypothesis Testing}

Before testing the hypothesis, this study has tested the classical assumptions including normality, multicollinearity, heteroscedasticity and autocorrelation tests. From the classical assumption test, it can be concluded that the data are passed the classical assumption test and can be continued for hypothesis testing. Based on the results of hypothesis testing, it can be seen in table 2 below:

Table 2. Hypothesis Testing

\begin{tabular}{lcccc}
\hline \multicolumn{1}{c}{ Variable } & Coefficient & $\begin{array}{c}\text { Significant of } \\
\text { 2-Tailed }\end{array}$ & $\begin{array}{c}\text { Significant } \\
\text { 1-Tailed }\end{array}$ & Results \\
\hline Constant & -1.956 & 0.079 & & \\
RPTAL & 2.718 & 0.151 & 0.075 & Accepted (moderate level) \\
RPTSE & -0.725 & 0.211 & 0.106 & Rejected \\
COMIN*RPTAL & -8.690 & 0.019 & 0.010 & Weaken \\
COMIN*RPTSE & 2.102 & 0.043 & 0.022 & Weaken \\
ACOM*RPTAL & 1.320 & 0.452 & 0.226 & Rejected \\
ACOM*RPTSE & -0.284 & 0.570 & 0.285 & Rejected \\
Profitability & 12.536 & 0.000 & 0.000 & Accepted \\
Firm size & 0.092 & 0.019 & 0.010 & Accepted \\
Adjusted R-Squared & \multicolumn{3}{c}{0.484} \\
Probability (F-Statistic) & \multicolumn{3}{c}{0.000} \\
F-Statistics & \multicolumn{3}{c}{ Source: Data processed 2021 } \\
\hline
\end{tabular}

Information:

RPTAL $=$ Related Party Transactions in Asset and Liability

RPTSE $=$ Related Party Transactions in Sales and Expense

COMIN $=$ Independent Commissioner

$\mathrm{ACOM}=$ Audit Committee

The adjusted R-squared value is 0,484 or $48,4 \%$, meaning that $48,4 \%$ of the independent variables affect the dependent variable and $51,6 \%$ are influenced by other variables outside this study. On table 4.2, it can be conclude that the probability of the F-Statistic is 0,0000 
$<0,05$. It can be shown at least 1 (one) independent variable can influencing the dependent variable. While the results of the t-test can be seen as follows:

a) H1a: RPTAL to Firm Value

The result of RPTAL coefficient is 2,718 . This means that the theory test which states there is a positive effect between related party transactions as measured by RPTAL on firm value is proven (passed the theory test), so that it can be continued into statistical tests. From the results of statistical tests obtained p-value of $0,075(0,151 / 2)$, this means that the p-value $<$ significant value $(0,075<0.10)$. Thus, it can be concluded that Ha is rejected.

b) H1b: RPTSE on Firm Value

The results of RPTSE coefficient data processing are $-0,725$. This means that the theory test which states that there is a positive effect between related party transactions as measured by RPTSE on firm value is not proven, so the magnitude of the p-value for this variable is not analyzed further. Based on the comes about, it can be concluded that H1b is rejected.

c) H2a: Independent Commissioner strengthens RPTAL on Firm Value

The result of Independent Commissioner's interaction coefficient with RPTAL is $-8,690$. This means that the theoretical test which states that the Independent Commissioner is strengthen the influence between related party transactions as measured by RPTAL on firm value is not proven, so it can be concluded that the existence of an Independent Commissioner does not strengthen the positive influence of RPTAL on firm value. Based on the comes about, it can be concluded that $\mathrm{H} 2 \mathrm{a}$ is rejected

d) H2b: Independent Commissioner strengthens RPTSE on Firm value

The comes about hypothesis testing of the Independent Commissioner's interaction coefficient with the RPTSE is 2,102. This means that the theory test which states that the Independent Commissioner is strengthen the influence of related party transactions as measured by RPTAL on firm value is not proven. This is because testing the RPTSE variable independently has no effect on firm value. So the magnitude of the p-value for this hypothesis was not analyzed further. Based on the results of the analysis, it can be concluded that $\mathrm{H} 2 \mathrm{~b}$ is rejected.

e) H3a: The Audit Committee strengthens the RPTAL on Firm Value

The comes about hypothesis testing of the interaction coefficient of the Audit Committee with RPTAL is 1,320 . This means that the theoretical test which states that the Audit Committee is able to strengthen the effect of related party transactions as measured by RPTAL on firm value is proven (passed the theory test), so it can be continued into statistical tests. From the results of statistical tests obtained p-value of $0,226(0,452 / 2)$, this means that the $\mathrm{p}$-value $>$ significant value $(0,226>0,10)$. Based on the comes about, it can be concluded that $\mathrm{H} 3 \mathrm{a}$ is rejected.

f) H3b: The Audit Committee strengthens the RPTSE on Firm Value

The comes about hypothesis testing the interaction coefficient between the Audit Committee and the RPTSE is $-0,284$. This means that the theory test which states that the Audit Committee strengthens the effect of related party transactions as measured by RPTSE on firm value is not proven, so the magnitude of the p-value for this variable is not analyzed further. Based on the comes about, it can be concluded that H3b is rejected.

g) Profitability on Firm Value

The comes about hypothesis testing of profitability coefficient of 12,536 . This means that the theory test which states there is a positive influence between profitability on firm value is proven (passed the theory test), so it can be continued into statistical tests. From the results of statistical tests obtained p-value of $0,000(0,000 / 2)$, this means that the p-value $<$ 
significant value $(0,000<0,10)$. It can be concluded the profitability has a positive impact on firm value.

h) Firm size on Firm Value

The results of the data processing firm size coefficient of 0,092 . This means that the theory test which states there is a positive influence between firm size on firm value is proven (passed the theory test), so it can be continued into statistical tests. From the results of statistical tests obtained p-value of $0,010(0,019 / 2)$, this means that the p-value < significant value $(0,010<0,10)$. It can be concluded the firm size has a positive impact on Firm Value.

\subsection{Results and Discussion}

\subsubsection{The Effect of RPTAL on Firm Value}

The comes about hypothesis testing 1a show that RPTAL has a positive impact on firm value. This contradicts the hypothesis which states that related party transactions as measured by RPTAL have a negative effect on firm value. This is in line with [34] which states related parties transactions of assets and liabilities are used as a means to reduce the risks when conducting transactions with third parties, such as transaction time and fees. [11] proved that related party asset transactions can improve the firm value because it could be considered as a form of support to improve company performance.

\subsubsection{The Effect of RPTSE on Firm Value}

The comes about hypothesis testing $1 \mathrm{~b}$ indicate the RPTSE has no effect on firm value. This finding is consistent with [35] which found that sales and purchase of related party transactions does not affect firm value. This means that there is no utilization with the use of related party transactions in terms of sales and purchases to increase firm value. Furthermore, it could be due to a regulation from the Director General of Taxes that binds companies to implement the arm's length principle, namely PER-32/PJ/2011, so that companies cannot set prices arbitrarily. This also prevents investors from reacting to sales and purchases of related party transactions [35].

\subsubsection{The Role of Independent Commissioners in Moderating the Effect of RPTAL and RPTSE on Firm Value}

The comes about hypothesis testing $2 \mathrm{a}$ indicates that the Independent Commissioner is weaken the positive effect of RPTAL on Firm Value. The result of testing hypotheses $2 b$ indicates that the Independent Commissioner is weaken the negative effect of RPTSE on firm value. Lo (2011) states that the high percentage of Independent Commissioners allows companies to disclose the size of transactions with related parties in more detail. Companies that have a higher percentage of Independent Commissioners tend to disclose details of related party transactions. This condition allows investors to be relatively aware of related party transactions in manufacturing companies, so investors are more careful in reacting to information on the amount of related party transactions. The selection of Independent Commissioners of manufacturing companies is dominated by accounting and economic education backgrounds [37]. This shows that the huge number of Independent Commissioners in the company, will increase the disclosure of related party transactions based on PSAK No. 7 of 2015 [31]. 


\subsubsection{The Role of the Audit Committee in Moderating the Effect of RPTAL and RPTSE on Firm value}

The results of testing hypotheses $3 \mathrm{a}$ and $3 \mathrm{~b}$ indicate that the Audit Committee can't moderate the effect of RPTAL and RPTSE on firm value. The ineffectiveness of the Audit Committee is supported by research conducted by [38] which found that the Audit Committee was not able to increase firm value. The Audit Committee still focus in detecting errors and fraud in transactions that often occur on a daily basis, not in transactions with related parties (Balim, 2013 in [39]). [40] stated that the existence of financial experts on the Audit Committee is not proficient in providing the best investment options for investors. This is because the financial expert has not been able to guarantee that no manipulation will occur. Rohmah \& Ahalik (2020) found that the Audit Committee had no effect on firm value. Thus, suggesting that the Audit Committee is still unable to effectively monitor the performance of the management so that the impact on the extent of disclosure of financial statement information will also not be effective. The members of the Audit Committee are required to have the capability, expertise and knowledge in the field of auditing as well as an understanding of the company's business processes so that they are able to work professionally [41].

\subsubsection{The Effect of Profitability on Firm Value}

This test shows that profitability positively and significantly impact the firm value. This result is supported by research by [42] who found that profitability impact firm value. Such result is consistent with [43] which found profitability to be affecting firm value. In this test it can be explained that the increase in the profitability of a company has an influence on the company value, meaning that the profit generated by the company is a consideration in measuring the company value [42]. Based on signaling theory, highly profitable companies will provide information to their shareholders that the company has a good business. In addition, the high level of profitability of a company is able to attract investors to invest [43]. This is because for equity investors, profit is the only determining factor for changes in the value of a security effect, so that profitability is one of the basis for assessing the condition of a company [44].

\subsubsection{The Effect of Firm size on Firm Value}

This test shows that the size of the company positively and significantly impact the value of the company. Such finding is supported by the study of [45] who found that the size of the company affect the value of the company. Additionally, it is also consistent with the finding by [46] who found that firm size had an effect on firm value. The result obtained could be explain by reflecting that as the firm value increases, it would be easier for the firm to gain capital and financing from different sources, both internally and externally. Therefore, the larger the firm size, the more opportunities to increase the firm value. In addition, the larger of the company have the lower risk, so that it can attract investors to invest. Large companies also have moreover better control over market conditions so that companies are able to confront economic competition better [44]. 


\section{Conclusion, Limitations and Implications}

\subsection{Conclusion}

As per the findings and discussion in this study, the conclusions could be summarised below:

a. Related party transactions measured using RPTAL positively and significantly impact (at moderate level) the firm value. One of the reasons for this could be that transactions in related party assets and liabilities can reduce risks related to transaction time and costs [10].

b. Related party transactions measured using RPTSE does not impact firm value. The regulation of the Director General of Taxes regarding the application of the arm's length principle (PER-32/PJ/2011) which makes companies unable to apply prices arbitrarily and makes investors unresponsive to sales and purchases of related party transactions [35].

c. Independent Commissioners weaken the positive impact of RPTAL on Firm Value and the negative impact of RPTSE on Firm Value. This suggests that the presence of more Independent Commissioners will disclose transactions with related parties in detail, so that investors will be more careful in responding to information regarding the size of related party transactions (Lo, 2011).

d. The Audit Committee does not impact the influence of related party transactions, both based on RPTAL and RPTSE, on Firm Value. This is because he Audit Committee still focus in detecting errors and fraud in transactions that often occur on a daily basis, not in transactions with related parties (Balim, 2013 in [39]).

e. Profitability positively impact the firm value. This states that the firm value increases as the profitability increases [44].

f. Firm size positively impact the firm value. This states that the firm value increases as the size of the company increases [44].

\subsection{Limitations}

This research certainly has limitations. First, this research only uses the magnitude instead of the extent of disclosures of related party transactions. Investors need more complete information in making decisions which might affect the value of the company. Second, this study does not examine in more detail the types of related party transactions, which if done so, might give a different result where it would affect the firm value differently.

\subsection{Implications}

Based on the conclusions to the findings and discussions that have been put forward in this study, the implications of this research are:

a. The regulator can continue to encourage companies to increase disclosures related to related party transactions in increasing the transparency of financial statements, and improve the quality of corporate governance practices,

b. Investors are expected to be more careful in making decision about investment in companies whose ownership is concentrated. This is because concentrated ownership can encourage the misuse of related party transactions. Investor can consider the disclosure of information about related party transaction, instead of the amount of transaction. 


\section{References}

[1] C. A. Utama, "Penentu Besaran Transaksi Pihak Berelasi: Tata Kelola, Tingkat Pengungkapan, Dan Struktur Kepemilikan," J. Akunt. dan Keuang. Indones., vol. 12, no. 1, pp. 37-54, 2015, doi: 10.21002/jaki.2015.03.

[2] D. Y. Anggraeni, "Relevansi Pengungkapan Transaksi Pihak Berelasi. Apakah Pasar Memberikan Respon?," TECHNOBIZ Int. J. Bus., vol. 1, no. 1, p. 25, 2018, doi: 10.33365/tb.v1i1.203.

[3] M. J. Conyon and L. He, "Executive compensation and corporate governance in China," J. Corp. Financ., vol. 17, no. 4, pp. 1158-1175, 2011, doi: 10.1016/j.jcorpfin.2011.04.006.

[4] B. Sun, "Executive compensation and earnings management under moral hazard," $J$. Econ. Dyn. Control, vol. 41, no. 985, pp. 276-290, 2014, doi: 10.1016/j.jedc.2014.02.004.

[5] F. S. Akmyga and A. Farahmita, "Pengaruh Struktur Corporate Governance terhadap Luas Pengungkapan Kompensasi Manajemen Kunci di Laporan Keuangan,” 2013.

[6] C. Bona-Sanchez, C. L. Fernandez-Senra, and J. Perez-Aleman, "Related-party Corporations," J. financ. econ., vol. 58, no. 1-2, pp. 81-112, 2017.

[7] C. Y. Liew, E. Alfan, and S. S. Devi, "Independent Directors' Tenure, Related Party Transactions, Expropriation and Firm Value: Evidence from Malaysian Firms," Pap. Present. 5th Int. Conf. Corp. Gov. Emerg. Mark. Leipzig, Ger., 2015.

[8] A. Pratama, "Do related party transactions and tax avoidance affect firm value?," Rev. Integr. Bus. Econ. Res., vol. 17, no. 1, pp. 106-116, 2018.

[9] R. M. K. Wong, J. Kim, and A. W. Y. Lo, “Are Related-Party Sales Value-Adding or Value-Destroying? Evidence from China,” J. Int. Financ. Manag., vol. 26, no. 1, pp. 1$38,2015$.

[10] Y. Chen, C. Chen, and W. Chen, "The impact of related party transactions on the operational performance of listed companies in China.," J. Econ. Policy Reform, vol. 12, no. 4, pp. 285-297, 2009.

[11] Q. Peng, K. C. J. Wei, and Z. Yang, "Tunneling or Propping: Evidence from Connected Transactions in China," J. Corp. Financ., vol. 17, pp. 306-325, 2011.

[12] I. K. Pebri, N. Diana, and Junaidi, "Pengaruh Good Corporate Governance dan Struktur Kepemilikan terhadap Tingkat Kepatuhan Pengungkapan Transaksi Berelasi Berdasarkan PSAK No. 7 Tentang Pengungkapan Pihak Berelasi.," E-JRA, vol. 9, no. 4, pp. 109-125, 2020.

[13] R. Wardhani, "Risiko ekspropriasi oleh pemilik pengendali dan tata kelola perusahaan terhadap tingkat penggunaan utang bank," J. Keuang. dan Perbank., vol. 19, no. 2, pp. 200-212, 2015.

[14] A. Haldar and M. Raithatha, "Do compositions of board and audit committee improve financial disclosures?,” Int. J. Organ. Anal., vol. 25, no. 2, pp. 251-269, 2017.

[15] Y. M. Sellami and H. B. Fendri, "The effect of audit committee characteristics on compliance with IFRS for related party disclosures: Evidence from South Africa," Manag. Audit. J., vol. 32, no. 6, pp. 603-626, 2017.

[16] Y. Lin, "The consequences of audit committee quality," Manag. Audit. J., vol. 33, no. 2, pp. 192-216, 2018.

[17] D. Ernawati and Y. A. Aryani, "Controlling Shareholders, Audit Committee Characteristics, and Related party Transaction Disclosure: Evidence from Indonesia," J. Keuang. dan Perbank., vol. 23, no. 1, pp. 15-30, 2019. 
[18] C. A. Utama and S. Utama, "Corporate governance, size and disclosure of related party transactions, and firm value: Indonesia Evidence,” Int. J. Discl. Gov., vol. 11, no. 4, pp. 341-365, 2014.

[19] M. C. Jensen and W. H. Meckling, "Theory of the Firm: Managerial Behavior, Agency Costs and Ownership Structure,” J. financ. econ., vol. 3, no. 4, pp. 305-360, 1976.

[20] V. Ratnawati, M. A. Hamid, and O. M. J. Popola, "The Influence of Agency Conflict Types I and II on Earnings Management," Int. J. Econ. Financ. Issues, vol. 6, no. 54, pp. 126-131, 2016.

[21] R. Rohi-Mone, K. Budiansyah, Rinaningsih, and R. Yulianti, "Pengaruh Besaran Transaksi Pihak Berelasi terhadap Nilai Perusahaan pada Perusahaan Terdaftar di Bursa efek Indonesia,” J. PETA, vol. 5, no. 1, pp. 1-26, 2020.

[22] Felix and Hanna, "The Effect of Governance, Disclosure levels, and Audit Quality toward The Magnitude of Related party Transacyion.," Klabat Account. Rev., vol. 1, no. 1, pp. 1-13, 2020.

[23] R. R. Ranitasari, Pengaruh DPK, LDR, CAR, NPL, dan NIM terhadap Penyaluran Kredit pada Perusahaan Perbankan Swasta Devisa Nasional yang Terdaftar di Bank Indonesia Periode 2011-2015. Surabaya: Sekolah Tinggi Ilmu Ekonomi Perbanas, 2017.

[24] M. Kohlbeck and B. W. Mayhew, "Valuation of Firms that Disclose Related Party Transactions.," J. Account. Public Policy, vol. 29, pp. 115-137, 2010.

[25] Moeljadi, "Factors Affecting Firm Value," South East Asia J. Contemp. Business, Econ. Law, vol. 5, no. 2, pp. 6-15, 2014.

[26] Z. Puspitaningtyas, "Efek Moderasi Kebijakan Dividen Dalam Pengaruh Profitabilitas Terhadap Nilai Perusahaan Manufaktur,” J. Akuntansi, Ekon. Dan Manaj. Bisnis, vol. 5, no. 2, pp. 173-180, 2017.

[27] R. W. Carney and N. Hamilton-Hart, "What Do Changes in Corporate Ownership in Indonesia Tell Us?,” Bull. Indones. Econ. Stud., vol. 51, no. 1, pp. 123-145, 2015, doi: 10.1080/00074918.2015.1016570.

[28] M. Kang, H. Lee, M. Lee, and J. C. Park, "The association between related-party transactions and control-ownership wedge: Evidence from Korea," Pacific-Basin Financ. J., vol. 29, pp. 272-296, 2014.

[29] H. Werdhi, "Pengaruh Corporate Governance Dan Karakteristik Perusahaan Terhadap Luas Pengungkapan Transaksi Pihak Berelasi Di Indonesia,” J. Akunt. Indones., 2015.

[30] H. W. Apriyani, "Pengaruh Corporate Governance Dan Karakteristik Perusahaan Terhadap Luas Pengungkapan Transaksi Pihak Berelasi Di Indonesia," J. Akunt. Indones., vol. 4, no. 1, p. 36, 2016, doi: 10.30659/jai.4.1.36-50.

[31] A. R. H. Pratista, "Pengaruh Corporate Governance Pada Kepatuhan Pengungkapan Transaksi Berelasi Berdasarkan Pernyataan Standar Akuntansi Keuangan (PSAK) No. 7 Tahun 2015," J. Nominal, vol. 8, no. 1, pp. 19-30, 2019.

[32] M. El-Halaly, "Related party transactions and accounting quality in Greece," Int. J. Account. Inf. Manag., vol. 24, no. 4, pp. 375-390, 2016.

[33] N. Marsha and I. Murtaqi, "The Effect of Financial Ratios on Firm Value in The Food and Beverage Sector of The IDX.," J. Bus. Manag., vol. 6, no. 2, pp. 214-226, 2017.

[34] K. H. Chen, J. M. Yien, K. P. Huang, and H. C. Jung, "Performance and its Link to Entrepreneurial Behavior,” Am. J. Appl. Sci., vol. 8, no. 7, pp. 703-707, 2011.

[35] A. Anggala and S. R. Basana, "Pengaruh Related Party Transaction Terhadap Nilai Perusahaan," Int. J. Financ. Invest. Stud., vol. 1, no. 1, pp. 42-52, 2020, doi: 10.9744/ijfis.1.1.42-52. 
[36] A. Lo, “An Empirical Stydy Of Voluntary Transfer Pricing Disclosure in China," $J$. Account.Public Policy, pp. 6007-6028, 2011.

[37] A. Firmansyah, P. A. Pamungkas, and F. M. Zainuddin, "Does Corporate Governance Increase Related Party Transaction Disclosure In Indonesia?," Econ. Account. J., vol. 4, no. 1, pp. 1-12, 2021.

[38] K. Valencia and S. Khairani, "Pengaruh Profitabilitas, Financial Distress, Dewan Komisaris Independen dan Komite Audit terhadap Nilai Perusahaan Dimediasi oleh Tax Avoidance (Studi Empiris Pada Perusahaan Sektor Industri Barang Konsumsi yang Terdaftar Di Bursa Efek Indonesia Periode 2,” J. Akunt., vol. 9, no. 1, pp. 47-62, 2019.

[39] Agnes, "Peranan Good Corporate Governance untuk Menekan Manipulasi Laba: Studi Mengenai Transaksi Pihak Berelasi,” Calyptra J. Ilm. Mhs. Univ. Surabaya, vol. 6, no. 2, pp. 310-324, 2017.

[40] M. Gianetti and A. Simonov, "Which Investors Fear Expropriation? Evidence from Investors' Portfolio Choices.," J. Finance, vol. 61, no. 3, pp. 1507-1547, 2006.

[41] M. A. Effendi, The power of Good Corporate Governance. (D. A. Halim, Ed.). Jakarta: Salemba Empat, 2016.

[42] I. Nurhayati and A. Kartika, "Pengaruh Struktur Modal Dan Profitabilitas Terhadap Nilai Perusahaan dengan Kebijakan Dividen sebagai Variabel Moderasi Pada Perusahaan Manufaktur Tahun 2016-2018," Din. Akuntansi, Keuang. dan Perbank., vol. 9, no. 2, pp. 133-144, 2020.

[43] K. R. Jamani and T. Erawati, "Pengaruh Profitabilitas terhadap Nilai Perusahaan dengan Struktur Modal Sebagai Variabel Intervening Pada Perusahaan Manufaktur yang Terdaftar Di BEI," J. Kaji. Bisnis, vol. 28, no. 1, pp. 51-70, 2020.

[44] Hery, Kajian Riset Akuntansi Mengulas Berbagai Hasil Penelitian dalam Bidang Akuntansi dan Keuangan. Jakarta: PT Grasindo,Anggota IKAPI, 2017.

[45] Dewi and Ekadjaja, "Pengaruh Profitabilitas, Likuiditas Dan Ukuran Perusahaan Terhadap Nilai Perusahaan Pada Perusahaan Manufaktur," J. Multiparadigma Akunt. Tarumanagara, vol. 2, no. 1, pp. 118-126, 2020.

[46] V. Loekito and L. W. Setiawati, "Analisis Pengaruh Corporate Social Responsibility, Ukuran Perusahaan, dan profitabilitas terhadap Nilai Perusahaan Pada Perusahaan Manufaktur yang Terdaftar Di Bursa Efek Indonesia Tahun 2017-2019,” Balanc. J. Akuntansi, Audit. dan Keuang., vol. 18, no. 1, pp. 1-26, 2021.

[47] "PSAK 7 Pengungkapan Pihak-Pihak Berelasi," 2018. 